\title{
EVALUASI TINGKAT KEBUGARAN JASMANI MAHASISWA PADA PERKULIAHAN PENDIDIKAN JASMANI IAIN SALATIGA
}

\author{
Fatkhur Rozi ${ }^{1}$, Setiorini Rahma Safitri', Amanda Syukriadi², \\ ${ }^{1}$ IAIN Salatiga, Kementerian Agama, Salatiga, \\ ${ }^{2}$ Universitas Syiah Kuala, Kementerian Pendidikan dan Kebudayaan, Aceh, \\ 1'fatkhur21@iainsalatiga.ac.id; 2amanda.syukriadi@unsyiah.ac.id
}

DOI : http://doi.org/10.37730/ edutrained.v5i1.121

Diterima: 2 Februari 2021 | Disetujui: 19 April 2021 | Dipublikasikan: 6 Juli 2021

\begin{abstract}
Abstrak
Tujuan penelitian ini adalah mengevaluasi tingkat kebugaran jasmani mahasiswa IAIN Salatiga setelah mengikuti perkuliahan pendidikan jasmani pada Semester Gasal 2020/2021. Metode penelitian ini adalah penelitian kuantitatif deskriptif dengan pendekatan survey. Hasil penelitian ini menunjukkan bahwa tingkat kebugaran jasmani mahasiswa laki-laki dengan kategori baik sebanyak 5 orang (33.3\%), kategori sedang sebanyak 9 orang (60\%), dan kategori kurang sebanyak 1 orang (6.7\%). Adapun mahasiswa perempuan dengan kategori baik sebanyak 25 orang $(25.3 \%)$, kategori sedang sebanyak 72 orang $(72.7 \%)$, dan kategori kurang sebanyak 2 orang $(2 \%)$. Simpulan penelitian ini adalah mahasiswa IAIN Salatiga yang mengikuti perkuliahan pendidikan jasmani secara umum memiliki tingkat kebugaran jasmani baik $(26.4 \%)$, sedangkan lainnya berada pada kategori sedang (71\%) dan kategori kurang (2.6\%). Saran dalam penelitian ini adalah Mahasiswa IAIN Salatiga selalu menjaga kebugaran jasmani pada kategori baik dan bagi peneliti selanjutnya dapat meneliti faktor yang mempengaruhi kebugaran Mahasiswa IAIN Salatiga.
\end{abstract}

Kata Kunci: evaluasi, kebugaran jasmani, pendidikan jasmani

\begin{abstract}
The purpose of this study was to evaluate the physical fitness level of IAIN Salatiga students after attending physical education lectures in the Odd Semester 2020/2021. This research method is descriptive quantitative research with a survey approach. The results of this study indicate that the physical fitness level of male students with good categories are 5 people (33.3\%), the adequate categories are 9 people (60\%), and in the poor category is 1 person (6.7\%). There were 25 female students in the good category (25.3\%), 72 people in the adequate category (72.7\%), and 2 students in the poor category (2\%). This research concludes that students of IAIN Salatiga who take physical education lectures generally have a good level of physical fitness (26.4\%), while others are in the adequate category (71\%) and the poor category (2.6\%). The suggestion in this research is that the students of IAIN Salatiga always maintain good physical fitness and for further researchers, they can examine the factors that affect the fitness of the students of IAIN Salatiga.
\end{abstract}

Keywords: evaluation, physical fitness, physical education 



\section{PENDAHULUAN}

Hadirnya Pandemi Covid-19 menjadikan kita sadar akan pentingnya kesehatan pada diri kita. Kesehatan dapat diperoleh dari pola hidup sehat, hidup bugar, dan pola makan serta pola istirahat yang cukup (Rozi, Azis Purnomo Shidiq, and Rahman 2021). Kebugaran jasmani dapat dihasilkan tubuh melalui pemenuhan aktivitas fisik dan olahraga yang teratur dan terukur. Kebugaran jasmani sendiri merupakan kemampuan tubuh untuk bekerja atau beraktivitas sehari-hari tanpa merasa lelah yang berarti (Nurhayati 2018). Pada masa pandemi, pemerintah menerbitkan aturan bahwa kegiatan dilaksanakan secara adaptasi baru yang disebut new normal (Gumantan, Mahfud, and Yuliandra 2020). Kebijakan tersebut juga berlaku untuk kegiatan pembelajaran baik pada tataran jenjang pra-sekolah sampai dengan perguruan tinggi. Untuk itu, pada masa adaptasi baru berkembang sistem pembelajaran secara daring (Sari and Sutapa 2020)

Pendidikan jasmani (penjas) dilaksanakan secara daring sebagaimana pembelajaran lainnya dijalankan. Selama daring, potensi penjas dapat dikembangkan (Herlina and Suherman 2020). Pembelajaran daring untuk mencegah penyebaran Virus Covid-19 (Anonim 2020). Penjas daring dilaksanakan dengan tetap memperhatikan tujuan penjas, salah satunya adalah tercapainya tingkat kebugaran jasmani yang baik. Penjas berperan dalam tercapainya kebugaran dan karakter anak (Darmawan 2017). Kebugaran yang baik akan meningkatkan imunitas tubuh sehingga membantu mencegah tertular virus ataupun membantu mempercepat pemulihan karena virus covid-19 (Pramudiarja 2020).

IAIN Salatiga merupakan salah satu Perguruan Tinggi Keagamaan Islam Negeri (PTKIN) yang memiliki mata kuliah pendidikan jasmani untuk program studi Pendidikan Guru Madrasah Ibtidaiyah (PGMI) dan
Pendidikan Anak Usia Dini (PIAUD). Selama Pandemi Covid-19 ini, pelaksanaan penjas secara daring diharapkan tetap berjalan optimal dan tentunya dapat tercapai salah satu tujuan penjas, yaitu kebugaran jasmani yang baik sebagai upaya pencegahan penyebaran covid-19. Untuk itu diperlukan evaluasi tentang tingkat kebugaran mahasiswa setelah melakukan perkuliahan penjas secara daring. Penelitian ini untuk mengungkap tingkat kebugaran jasmani Mahasiswa IAIN Salatiga setelah perkuliahan pendidikan jasmani. Penelitihan ini penting dilakukan untuk mengevaluasi proses perkuliahan pendidikan jasmani di IAIN Salatiga terkait efektivitasnya dalam pencapaian kebugaran jasmani mahasiswa.

\section{KAJIAN PUSTAKA}

Kebugaran jasmani adalah kondisi dimana seseorang dapat beraktivitas secara maksimal tanpa mengalami kelelahan yang begitu berarti (Kurnianto 2015). Kebugaran jasmani merupakan salah satu faktor penting bagi peserta didik untuk melakukan aktivitas fisik dan olahraga serta berdampak positif untuk perkembangan kognitif, psikomotor, dan afektif (Suhartoyo et al. 2019). Dengan pengelolaan pembelajaran yang baik nantinya akan meningkatkan kebugaran jasmani peserta didik sesuai dengan salah satu tujuan penjas (Darmawan 2017).

Faktor yang mempengaruhi kebugaran jasmani seseorang salah satunya adalah asupan gizi dari kualitas makanan (Sulistiono 2014). Usia, jenis kelamin, bentuk tubuh, tingkat kesehatan, berat badan, pola istirahat dan kegiatan fisik merupakan faktorfaktor yang berpengaruh terhadap tingkat kebugaran jasmani (Mukti 2014). Selain itu, faktor indeks masa tubuh, dan latihan fisik juga berpengaruh terhadap kebugaran jasmani (Salamah 2019).

Manfaat kebugaran jasmani sendiri adalah menjaga kualitas kesehatan. Dengan kebugaran yang baik akan 

meningkatkan imunitas tubuh (Darmawan 2017). Selain itu, dengan kebugaran jasmani yang baik akan meningkatkan produktivitas dalam belajar (Pratiwi 2018). Kebugaran Jasmani dapat diperoleh dengan latihan fisik atau olahraga yang terukur secara teratur (Kurnianto 2015).

Evaluasi terhadap kebugaran jasmani dapat dilakukan dengan melakukan Tes sesuai dengan Asian Committee on the Standardization of Physical Fitness Test (A.C.S.P.F.T) yang terdiri dari tes lari cepat 50 meter, lompat jauh tanpa awalan, pull-up, gantung siku tekuk, situp, shuttle run, lentuk togok ke muka, dan lari 1000/800 meter (putra/putri) (Suharjana and Purwanto 2008). Selain itu, tes kebugaran jasmani dapat dilakukan dengan melakukan Tes Kebugaran Jasmani Indonesia (TKJI) (Permana 2020). Kemampuan jalan kaki dalam satuan waktu tertentu juga dapat digunakan untuk mengukur kebugaran (Anon 2011).

\section{METODE PENELITIAN}

Penelitian ini adalah jenis penelitian kuantitatif dengan teknik survei. Penelitian dilaksanakan di IAIN Salatiga pada Bulan November 2020. Populasi dalam penelitian ini adalah 127 mahasiswa IAIN Salatiga yang mengikuti perkuliahan pendidikan jasmani. Teknik sampling yang digunakan adalah Simple Random Sampling dimana berjumlah 114 mahasiswa dengan tingkat margin of eror $3 \%$ sesuai dengan rumus Slovin. Teknik pengambilan data menggunakan Tes Kebugaran Jasmani dari Dr. Nina dengan cara mengukur kemampuan jarak tempuh jalan kaki selama enam menit (Anon 2011). Teknik analisis data yang digunakan dalam penelitian ini adalah teknik analisis deskriptif persentase. Data dalam penelitian ini disajikan dalam bentuk tabel dan diagram.

\section{HASIL PENELITIAN DAN PEMBAHASAN}

\section{Hasil Penelitian}

Berdasarkan hasil evaluasi tingkat kebugaran jasmani Mahasiswa IAIN Salatiga setelah mengikuti perkuliahan penjas selama satu semester didapati hasil yang tergambar pada tabel berikut ini.

Tabel 1 Hasil Tes Kebugaran Jasmani

\begin{tabular}{lccc}
\hline Mahasiswa & Baik & Sedang & Kurang \\
\hline Laki-Laki & 5 & 9 & 1 \\
\hline Perempuan & 25 & 72 & 2 \\
\hline Sub Total & 30 & 81 & 3 \\
\hline
\end{tabular}

Sampel di atas menunjukkan bahwa mahasiswa laki-laki lebih sedikit daripada mahasiswa perempuan. Hal ini dikarenakan populasi yang ada didominasi oleh mahasiswa perempuan. Hasil tersebut berdasarkan tes kebugaran jasmani menggunakan tes jalan kaki sesuai tes dari Dr. Nina, yaitu pengukuran jarak tempuh dari hasil jalan kaki selama enam menit. Jika dipersentasekan maka akan didapati data sebagai berikut.

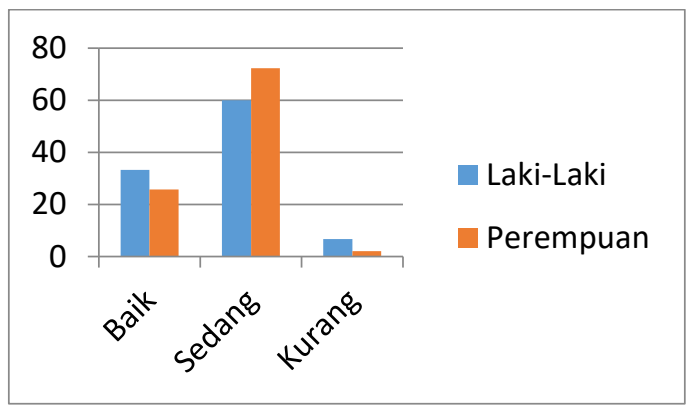

Gambar 1 Persentase Hasil Tes Kebugaran

Hasil tes kebugaran jasmani yang telah dilakukan menunjukkan bahwa mahasiswa laki-laki sebanyak 33.3\% kategori baik, 60\% kategori sedang, dan 6,7 kategori kurang. Sedangkan mahasiswa perempuan sebanyak $25.7 \%$ kategori baik, $72.3 \%$ kategori sedang, dan $2 \%$ kategori kurang.

\section{Pembahasan}

Kebugaran jasmani merupakan suatu yang penting bagi kesehatan semua orang. Namun, kenyataannya Mahasiswa IAIN Salatiga yang telah mengikuti 
perkuliahan penjas tidak seluruhnya berada pada kategori baik. Dari tabel 1 dapat dilihat bahwa yang memiliki kategori baik hanya $30 \quad(26.4 \%)$ mahasiswa dari jumlah total 114 mahasiswa yang dites. Hasil lainnya adalah $80(71 \%)$ mahasiswa berada pada kategori sedang. Pada kategori kurang menjadi catatan penting karena masih didapati 3 (2\%) mahasiswa pada kategori ini. Hal ini tentunya menjadi sebuah catatan karena hanya $26.4 \%$ yang berada pada kategori baik. Tentunya sebagai evaluasi dosen untuk mencari cara agar hasil pembelajaran penjas dapat tercapai dengan baik khususnya pada ranah ketercapaian kebugaran mahasiswa. Harapannya ke depan tingkat mahasiswa yang memiliki kebugaran jasmani baik adalah $80 \%$ dari total mahasiswa yang mengikuti. Pembelajaran yang baik dapat dilihat dari tingkat keberasilan peserta didik yang tuntas sebanyak lebih dari $80 \%$ (Sulistiawan 2020).

Jumlah mahasiswa yang begitu timpang antara laki-laki dengan perempuan juga dapat mempengaruhi hasil belajar penjas. Tercatat hanya 15 mahasiswa laki-laki dibandingkan perempuan yang berjumlah 99 mahasiswa. Adanya jumlah yang lebih besar pada mahasiswa perempuan mengharuskan dosen memberikan bentuk kegiatan penjas yang disesuaikan jika dibandingkan dengan mahasiswa laki-laki terlebih pembelajaran penjas yang dijalankan secara daring. Modifikasi dapat dilakukan selama pembelajaran penjas untuk meningkatkan motivasi dan hasil (Ichwan, Surya, and Hasyim 2018). Begitupun demikian, untuk mahasiswa laki-laki dibuatkan program tersendiri. Hal ini khusus catatan pada materi kebugaran jasmani. Kebugaran jasmani menjadi penting dalam hal meingkatkan konsentrasi (Nurhayati 2018).

Secara umum capaian evaluasi tingkat kebugaran jasmani Mahasiswa IAIN Salatiga yang telah mengikuti perkuliahan penjas secara daring tidak sepenuhnya buruk. Mayoritas mahasiswa yang berada pada kategori sedang (70\%) sebenarnya dapat meningkatkan tingkat kebugaran jasmaninya pada kategori baik dengan meningkatkan frekuensi latihan kebugaran jasmani. Pada penelitian ini kenyataannya adalah mahasiswa melakukan kegiatan mandiri selama perkuliahan daring penjas dengan total pertemuan 16 kali dengan dua diantaranya untuk UTS dan UAS. Jika mengharap adanya peningkatan latihan kebugaran jasmani, maka mahasiswa perlu melakukan latihan lebih terstruktur dengan pemenuhan durasi dan secara rutin. Kesadaran akan pentingnya kebugaran jasmani akan mempengaruhi mahasiswa dalam berlatih. Tes kebugaran jasmani pada mahasiswa untuk mengevaluasi tingkat kebugarannya (Pratiwi 2018).

Latihan rutin kebugaran jasmani dapat dilakukan dengan beberapa variasi dengan tetap mempertahankan tujuan utama yaitu melatih komponen kebugaran jasmani secara menyeluruh. Dengan latihan rutin yang dilakukan mahasiswa nantinya dapat dihasilkan peningkatan kebugaran jasmaninya. Kebugaran jasmani yang baik dapat dihasilkan melalui latihan kebugaran jasmani (Darmawan 2017).

\section{PENUTUP}

\section{Simpulan}

Simpulan penelitian ini adalah mahasiswa IAIN Salatiga yang mengikuti perkuliahan pendidikan jasmani secara umum memiliki tingkat kebugaran jasmani baik (26.4\%), sedangkan lainnya berada pada kategori sedang (71\%) dan kategori kurang (2.6\%) yang dipengaruhi oleh usia, jenis kelamin, aktivitas fisik, gizi, dan pola istirahat.

\section{Saran}

Saran dalam penelitian ini adalah Mahasiswa IAIN Salatiga selalu menjaga kebugaran jasmani pada kategori baik dan bagi peneliti selanjutnya dapat meneliti faktor yang mempengaruhi kebugaran Mahasiswa IAIN Salatiga. 


\section{DAFTAR PUSTAKA}

Anon. 2011. "Calon Haji Bisa Tes Daya Tahan Tubuhnya Dengan Jalan 6 Menit." Health.Detik.Com 1. Retrieved (https://health.detik.com/berita-detikhealth/d1721414/calon-haji-bisa-tes-daya-tahan-tubuhnya-dengan-jalan-6-menit).

Anonim. 2020. "Pembelajaran Secara Daring Dan Bekerja Dari Rumah Untuk Mencegah Penyebaran Covid-19." Kemdikbud.Go.Id 1-2. Retrieved (https://www.kemdikbud.go.id/main/blog/2020/03/se-mendikbudpembelajaran-secara-daring-dan-bekerja-dari-rumah-untuk-mencegahpenyebaran-covid19).

Darmawan, I. 2017. "Upaya Meningkatkan Kebugaran Jasmani Siswa Melalui Penjas.” JIP [Internet] 7(2):143-54.

Gumantan, Aditya, Imam Mahfud, and Rizki Yuliandra. 2020. "Pemberlakuan New Normal Dan Pengetahuan." Sport Scienc and Education Journal 1(2):18-27.

Herlina, Herlina and Maman Suherman. 2020. "Potensi Pembelajaran Pendidikan Jasmani Olahraga Dan Kesehatan (Pjok) Di Tengah Pandemi Corona Virus Disease (Covid)-19 Di Sekolah Dasar." Tadulako Journal Sport Sciences And Physical Education 8(1):1-7.

Ichwan, Dicky Miftahul, Mohammad Surya, and Abdul Hasyim. 2018. "Pengaruh Modifikasi Alat Pembelajaran Penjas Dalam Meningkatkan Motivasi dan Hasil Belajar Siswa Pada Mata Pelajaran Penjas di SMP PGRI Bungbulang Tahun Pelajaran 2014/2015." TEKNOLOGI PEMBELAJARAN 3(2).

Kurnianto, D. 2015. "Menjaga Kesehatan Di Usia Lanjut.” Jurnal Olahraga Prestasi 11(2):115182.

Mukti, Anggi Fauzi. 2014. "PROFIL KEBUGARAN JASMANI DILIHAT DARI INDEKS MASSA TUBUH DI SMAN 9 BANDUNG." Universitas Pendidikan Indonesia.

Nurhayati, Titing. 2018. "The Application of Collant Racket Tennis Technology to Measure Service Skills: A Pilot Study on Junior Tennis Athletes." Pendidikan Jasmani Olahraga 3(1):122-28.

Permana, R. 2020. TEORI DAN PRAKTIK: PENDIDIKAN JASMANI DI PERGURUAN TINGGI. edited by Zulfikar. Tasikmalaya: Edu Publisher.

Pramudiarja, AN Uyung. 2020. “4 Kunci Menjaga Kebugaran Agar Tak Gampang Kena Corona." De3tik.Health.Com 1. Retrieved (https://health.detik.com/kebugaran/d-5198954/4-kunci-menjagakebugaran-agar-tak-gampang-kena-corona).

Pratiwi, Firda Duta. 2018. “Tingkat Kebugaran Jasmani Mahasiswa Jurusan Pendidikan Jasmani Dan Kesehatan Angkatan Tahun 2014 FIK Universitas Negeri Malang." Universitas Negeri Malang.

Rozi, Fatkhur, Abdul Azis Purnomo Shidiq, and Alvin Yanuar Rahman. 2021. “Aspek Aman, Imun, dan Iman Pada Pembelajaran Pendidikan Jasmani di IAIN Salatiga Selama Pandemi Covid-19 [The Aspects Of Safety, Immunity, and Faith in Physical Education Learning at IAIN Salatiga During The Covid-19 Pandemic]." POLYGLOT: JURNAL ILMIAH 17(1):145-58.

Salamah, Rhosidatus. 2019. "Hubungan Asupan Zat Gizi, Aktivitas Fisik, Dan Persentase Lemak Tubuh Dengan Kebugaran Jasmani." MEDIA KESEHATAN MASYARAKAT INDONESIA 18(2):14-18.

Sari, Dyah Purnama and Panggung Sutapa. 2020. EFEKTIVITAS PEMBELAJARAN JARAK JAUH DENGAN DARING SELAMA PANDEMI COVID-19 MATA PELAJARAN 

PENDIDIKAN JASMANI OLAHRAGA DAN KESEHATAN (PJOK).

Suharjana, F. and Heri Purwanto. 2008. "Kebugaran Jasmani Mahasiswa D II PGSD Penjas FIK UNY." Jurnal Pendidikan Jasmani Indonesia 5(2):64-73.

Suhartoyo, Topo, Didik Rilastiyo Budi, Moh. Nanang Himawan Kusuma, Muhamad Syafei, Arfin Deri Listiandi, and Rohman Hidayat. 2019. "Identifikasi Kebugaran Jasmani Siswa SMP Di Daerah Dataran Tinggi Kabupaten Banyumas." Physical Activity Journal (PAJU) 1(1):8-17.

Sulistiawan, Rendra Wempi. 2020. "Penggunaan Metode Drill Untuk Meningkatkan Hasil Belajar Kombinasi Pola Gerak Dasar Lompat Jauh Pada Siswa Kelas V SD Negeri 1 Kedungrejo Kecamatan Nguntoronadi Kabupaten Wonogiri Tahun Pelajaran 2018/2019." JIGI: Jurnal Ilmiah Guru Indonesia 1(1):1-18.

Sulistiono, Agus Amin. 2014. "Kebugaran Jasmani Siswa Pendidikan Dasar Dan Menengah Di Jawa Barat." C Jurnal Pendidikan Dan Kebudayaan 20(2):223-33. 